\title{
High density of IgG4-secreting plasma cells in the fibrotic tissue from a surgically resected tracheal ring impaired by complex subglottic stenosis post-tracheostomy as immune expression of a $\mathrm{T}_{\mathrm{h}} 2$ response due to severe COVID-19
}

\author{
Luca Roncati ${ }^{1,2}$ (I) Giuliano Bergonzini ${ }^{3} \cdot$ Beatrice Lusenti ${ }^{1} \cdot$ Vincenzo Nasillo ${ }^{1} \cdot$ Ambra Paolini $^{1} \cdot$ Giuliana Zanelli $^{2}$. \\ Stefania Corrado ${ }^{2}$
}

Received: 15 August 2020 / Accepted: 24 August 2020 / Published online: 28 August 2020

(C) Springer-Verlag GmbH Germany, part of Springer Nature 2020

Dear Editor,

Coronavirus disease 2019 (COVID-19) is a global health emergency without precedents, that is causing hundreds of thousands of victims and impairing, to some extent, the quality of life of those patients survived to the most severe form of the disease $[1,2]$. In this regard, a 67 -year-old male patient was admitted to the intensive care unit for bilateral pneumonia from Severe Acute Respiratory Syndrome Coronavirus 2 (SARS-CoV-2) infection, as proven by nasopharyngeal swab positivity. The clinical picture was so serious that endotracheal intubation and then tracheostomy were required; despite all, the patient was saved, and he was discharged from the hospital. Three and a half months after admission, a second hospitalization was necessary due to complex subglottic stenosis, and the surgical resection of a tracheal ring was performed. Besides exuberant fibrosis, histology and immunohistochemistry revealed a high localized density of immunoglobulin G4 (IgG4)-secreting plasma cells inside the fibrotic tissue (Fig. 1); contrariwise, IgG4 dosage on serum was found within the normal range $(43 \mathrm{mg} / \mathrm{dL})$. As well known, IgG4-related disease (IgG4-RD) is a chronic immune-mediated condition, which occurs most frequently in middle-aged and elderly men, characterized by tissue infiltration with lymphocytes

Luca Roncati

roncati.luca@aou.mo.it; luca.roncati@unimore.it;

emailmedical@gmail.com

1 Hemolymphopathology Team, University Hospital of Modena, Largo del Pozzo 71, 41124 Modena, Italy

2 Surgical Pathology, University Hospital of Modena, Modena, Italy

3 Clinical Pathology, University Hospital of Modena, Modena, Italy and IgG4-secreting plasma cells, various degrees of storiform fibrosis, and a usually prompt improvement by oral steroids [3]. The connective deposition in the affected anatomical site can lead to mass-forming tumor-like lesions and organ dysfunctions [3]. Severe SARS-CoV-2 infections are associated with marked $\mathrm{T}$ cytotoxic $\left(\mathrm{T}_{\mathrm{c}}\right)$ lymphopenia [4], and, in these life-threatening cases, the immune system is forced to mount a $\mathrm{T}$ helper $2\left(\mathrm{~T}_{\mathrm{h}} 2\right)$ response (humoral immunity), the only one still mountable in the attempt to counteract the viral load, rather than a $\mathrm{T}$ helper 1 response (cell-mediated immunity), which would keep the infection under control by means of $T_{c}$ lymphocytes and macrophages [5-8]. Because regulation of IgG4 switching is dependent by $\mathrm{T}_{\mathrm{h}} 2$ cells [9], it is possible that the $\mathrm{T}_{\mathrm{h}} 2$ response, induced by serious SARS-CoV-2 infections, triggers in some patients a localized IgG4 hyperproduction with subsequent scarring sequelae, in particular at the level of the respiratory tract, even in the absence of IgG4-RD. In addition, since advanced age, male sex, and chronic comorbidities are risk factors for COVID-19 mortality [10], IgG4$\mathrm{RD}$ patients appear at higher risk of progressing to critical state once infected, and thus need to be identified and properly managed.

\section{Compliance with ethical standards}

Conflict of interest The authors declare that they have no conflict of interest.

Ethical approval All procedures followed were in accordance with the ethical standards and with the Helsinki Declaration of 1975, as revised in 2008.

Informed consent Not applicable since the manuscript does not contain any patient data. 


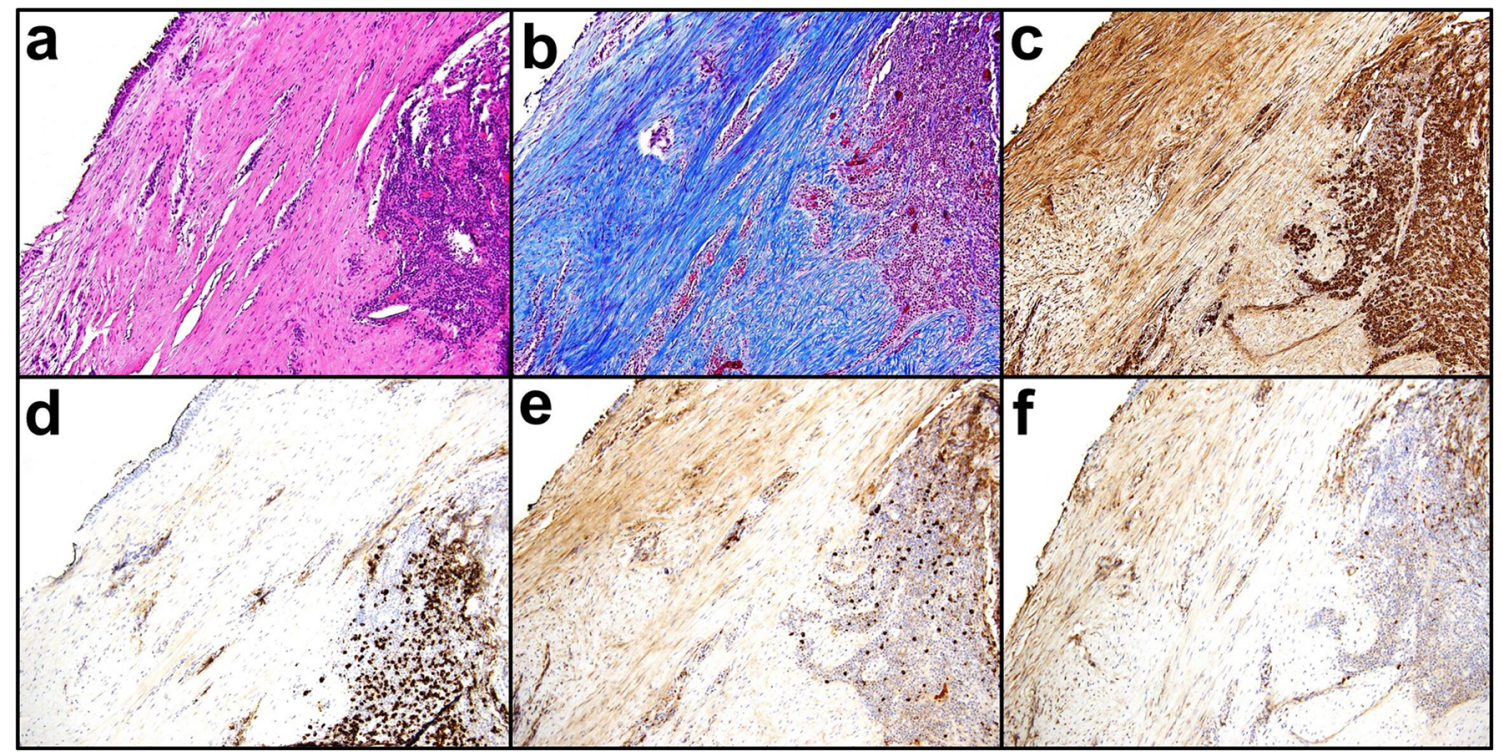

Fig. 1 Histological section of the tracheal ring with fibrosis and plasma cell infiltration (a, hematoxylin \& eosin, $\times 10$ objective); Masson's trichrome stains in blue the disrupting fibrotic reaction $(\mathbf{b}, \times 10$ objective); on immunohistochemistry, plasma cells are mainly IgGsecreting elements (c, polyclonal, $\times 10$ objective), with a high tissue

\section{References}

1. Halpin SJ, McIvor C, Whyatt G, Adams A, Harvey O, McLean L, Walshaw C, Kemp S, Corrado J, Singh R, Collins T, O'Connor RJ, Sivan M (2020) Post-discharge symptoms and rehabilitation needs in survivors of COVID-19 infection: a cross-sectional evaluation. J Med Virol. https://doi.org/10.1002/jmv.26368

2. Roncati L, Gallo G, Manenti A, Palmieri B (2020) Reninangiotensin system: the unexpected flaw inside the human immune system revealed by SARS-CoV-2. Med Hypotheses 140:109686

3. Chen Y, Dong Y, Cai S, Ye C, Dong L (2020) Clinical characteristics of IgG4-RD patients infected with COVID-19 in Hubei, China. Semin Arthritis Rheum 50(4):559-563

4. Zhao Q, Meng M, Kumar R, Wu Y, Huang J, Deng Y, Weng Z, Yang L (2020) Lymphopenia is associated with severe coronavirus disease 2019 (COVID-19) infections: a systemic review and metaanalysis. Int J Infect Dis 96:131-135

5. Roncati L, Nasillo V, Lusenti B, Riva G (2020) Signals of Th2 immune response from COVID-19 patients requiring intensive care. Ann Hematol 99(6):1419-1420 density of IgG4 subclass (d, MRQ-44 clone, $\times 10$ objective), in number significantly superior to IgA- (e, polyclonal, $\times 10$ objective) and IgMsecreting plasma cells (f, polyclonal, $\times 10$ objective) (brownish chromogen: 3,3'-diaminobenzidine tetrahydrochloride)

6. Roncati L, Ligabue G, Fabbiani L, Malagoli C, Gallo G, Lusenti B, Nasillo V, Manenti A, Maiorana A (2020) Type 3 hypersensitivity in COVID-19 vasculitis. Clin Immunol 217:108487

7. Roncati L, Lusenti B (2020) The «moonlighting protein» able to explain the Th1 immune lockdown in severe COVID-19. Med Hypotheses 143:110087

8. Roncati L, Palmieri B (2020) What about the original antigenic sin of the humans versus SARS-CoV-2? Med Hypotheses 142:109824

9. Aalberse RC, Stapel SO, Schuurman J, Rispens T (2009) Immunoglobulin G4: an odd antibody. Clin Exp Allergy 39(4): 469-477

10. Li J, Huang DQ, Zou B, Yang H, Hui WZ, Rui F, Yee NTS, Liu C, Nerurkar SN, Kai JCY, Teng MLP, Li X, Zeng H, Borghi JA, Henry L, Cheung R, Nguyen MH (2020) Epidemiology of COVID-19: a systematic review and meta-analysis of clinical characteristics, risk factors and outcomes. J Med Virol. https://doi.org/ $10.1002 /$ jmv. 26424

Publisher's note Springer Nature remains neutral with regard to jurisdictional claims in published maps and institutional affiliations. 